\title{
PARAPLEGIA DUE TO DECOMPRESSION SICKNESS
}

\author{
By H. L. Frankel \\ National Spinal Injuries Centre, Stoke Mandeville Hospital, Aylesbury, U.K.
}

Key words: Paraplegia; Spinal cord injuries; Decompression sickness; Caisson disease; Diving; Sub-aqua swimming.

\section{Introduction}

THE clinical effects, suggested pathological mechanisms and the treatment of decompression sickness were described in the last century (Pol \& Watelle, I854; Bert, I878; Hill, I9I I). These early cases were underground workers engaged in tunnel and bridge building. Since then many cases have been described in divers and recently a few in those exposed to very low atmospheric pressures at high altitude.

At Stoke Mandeville Hospital we have seen eight cases of spinal cord damage due to diving with apparatus of varying degrees of sophistication.

\section{Case Reports}

The main clinical features of the patients are shown on Table I. The first three were professional divers who claim they conformed to normal decompression practice. Patient I was paraplegic on arrival at the surface, was recompressed and made a partial recovery. In Patient 2 there was some delay (probably hours) in recompression. He also made a partial recovery. Patient 3 lost consciousness and was wrongly diagnosed as having a heart attack, his recompression was delayed, he regained consciousness when recompressed to only 12 metres.

Patient 4 made a rapid ascent without decompression stops from 45 metres and developed an immediate paraplegia, there was a 4-hour delay before it was possible to recompress him; following a decompression over 36 hours, he was later treated in hyperbaric oxygen and made a partial recovery. Patient 5 was a semi-professional also using aqualung apparatus. He ascended from about 55 metres by using standard decompression stops and developed paralysis. He therefore returned to 45 metres with recovery. Following a second ascent, he was unwell but was able to walk to the ambulance. Following this there was a slow onset of quadriplegia. Local facilities only enabled him to be recompressed to 3 metres. He was transferred to the Royal Naval Hospital and several hours after the onset he was fully recompressed; he made a partial recovery from his quadriplegia. Patient number 6 had a very similar sequence of events the only difference being that he was taken to Cherbourg which was nearer and he developed a paraplegia and not a quadriplegia. Patient number 7 was an insulin-treated diabetic. He was accompanied to a depth of 27 metres by his trainer and after 15 minutes had a normal ascent at the end of which he lost consciousness. This was first thought to be due to hypoglycaemia. His recompression was delayed by 5 hours as there were no facilities locally. He made a partial recovery from his cerebral involvement and from his upper limb paralysis. He had a nearly but not quite complete paralysis of the lower limbs.

Patient 8 was a professional diver working from a Bell on an Oil Platform in the North Sea. He had been to a depth of 76 metres for approximately an hour and his companion was out of the Bell; as his companion returned to the Bell, the mooring broke and the entire Bell with its hatch open, rapidly ascended to the surface. The ascent took 42 seconds (the planned decompression for this depth and time would have been approximately 42 hours!). His companion died immediately. Our patient was conscious on 


\section{TABLE I}

Details of the eight patients observed

\begin{tabular}{|c|c|c|c|c|c|c|}
\hline \multicolumn{2}{|c|}{$\begin{array}{l}\text { Patient (Year } \\
\text { of accident) }\end{array}$} & $\begin{array}{l}\text { Diving } \\
\text { details }\end{array}$ & \multirow{2}{*}{$\begin{array}{l}\text { Treatment } \\
\begin{array}{l}\text { Compression } \\
\text { chamber }\end{array}\end{array}$} & \multirow{2}{*}{$\begin{array}{l}\begin{array}{l}\text { C.N.S. } \\
\text { lesion }\end{array} \\
\text { Paraplegia } \\
\text { T5 }\end{array}$} & \multirow{2}{*}{$\begin{array}{l}\text { Recovery } \\
\text { Partial. } \\
\text { Wheelchair }\end{array}$} & \multirow{2}{*}{$\begin{array}{l}\begin{array}{l}\text { Special } \\
\text { features }\end{array} \\
\text { Sores. } \\
\text { Pain }+\end{array}$} \\
\hline $\begin{array}{l}\text { I } \\
(1962)\end{array}$ & $\begin{array}{l}\text { Nava } \\
9 \mathrm{Im} \\
\text { Oxyg } \\
\text { 'acco } \\
\text { Stan }\end{array}$ & $\begin{array}{l}\text { diver (27). } \\
\text { en/helium } \\
\text { eding to } \\
\text { lard Tables' }\end{array}$ & & & & \\
\hline $\begin{array}{l}2 \\
(1965)\end{array}$ & $\begin{array}{l}\text { Turk } \\
\text { profe } \\
\text { diver }\end{array}$ & $\begin{array}{l}\text { ish } \\
\text { ssional skin } \\
\text { (32) }\end{array}$ & $\begin{array}{l}35 \mathrm{hrs} \text { in pressure } \\
\text { chamber }\end{array}$ & Quadriplegia & $\begin{array}{l}\text { Upper limbs } \\
\text { normal. } \\
\text { Spastic para- } \\
\text { paresis. } \\
\text { Walking with } \\
\text { crutches }\end{array}$ & $\begin{array}{l}\text { Sores. } \\
\text { Pain }++ \text {. } \\
\text { Uncooperative }\end{array}$ \\
\hline $\begin{array}{l}3 \\
(1969)\end{array}$ & $\begin{array}{l}\text { Profe } \\
\text { sea d } \\
\text { New } \\
43 \mathrm{~m} \\
\text { Unce } \\
\text { ? He }\end{array}$ & $\begin{array}{l}\text { ssional deep } \\
\text { iver (47) } \\
\text { haven. } \\
\times 2 \text {. } \\
\text { nscious. } \\
\text { rrt attack }\end{array}$ & $\begin{array}{l}\text { In chamber to } 12 \mathrm{~m} \text {. } \\
\text { Regained conscious- } \\
\text { ness. } \\
\text { H.M.S. Vernon } 50 \mathrm{~m}\end{array}$ & $\begin{array}{l}\text { Paraplegia } \\
\text { T5 }\end{array}$ & $\begin{array}{l}\text { Good. } \\
\text { Walking with } \\
\text { sticks }\end{array}$ & Pain + \\
\hline $\begin{array}{l}4 \\
(\mathrm{I} 968)\end{array}$ & $\begin{array}{l}\text { Italia } \\
\text { Prolc } \\
\text { dive. } \\
\text { Com } \\
\text { bom } \\
\text { ascer } \\
\text { para }\end{array}$ & $\begin{array}{l}\mathrm{n} \text { amateur (26). } \\
\text { nged } 45 \mathrm{~m} \\
\text { pressed 'Air } \\
\text { '. 2nd rapid } \\
\text { t. Immediate } \\
\text { legia }\end{array}$ & $\begin{array}{l}.4 \text { hrs. } \rightarrow \text { Italian Navy } \\
\text { decompression } \\
\text { chamber for } 36 \mathrm{hrs} \text {. } \\
5 \text { days later hyper- } \\
\text { baric oxygen }\end{array}$ & $\begin{array}{l}\text { T3 anterior } \\
\text { spinal artery } \\
\text { syndrome }\end{array}$ & $\begin{array}{l}\text { Good. } \\
\text { Walks with } \\
\text { crutches }\end{array}$ & $\begin{array}{l}\text { Sores. } \\
\text { No pain. } \\
\text { Excellent } \\
\text { personality }\end{array}$ \\
\hline $\begin{array}{l}5 \\
(1969)\end{array}$ & $\begin{array}{l}\text { Sem } \\
(20) \\
45-5 \\
\text { 'Star }\end{array}$ & $\begin{array}{l}\text {-professional } \\
\text { Guernsey. } \\
\text { m } 24 \text { min } \\
\text { dard Tables' }\end{array}$ & $\begin{array}{l}\text { Return to } 45 \mathrm{~m}- \\
\text { good recovery } 2 \mathrm{nd} \\
\text { ascent. } \\
\text { Walked to ambulance. } \\
\text { Slow onset of quadri- } \\
\text { plegia. } \\
\text { Frigate } 3 \mathrm{~m} \rightarrow \text { R.N.H. } \\
\text { Haslar } 76 \mathrm{~m}(47 \mathrm{hrs})\end{array}$ & Quadriplegia & $\begin{array}{l}\text { Partial. } \\
\text { Walks with } \\
\text { sticks }\end{array}$ & $\begin{array}{l}\text { Excellent } \\
\text { rehabilitation. } \\
\text { Euphoric }\end{array}$ \\
\hline $\begin{array}{l}6 \\
(1972)\end{array}$ & $\begin{array}{l}\text { Sem } \\
(25) \\
53 \mathrm{~m} \\
3 \mathrm{me} \\
\text { (ther } \\
\text { Wea } \\
\text { pleg. }\end{array}$ & $\begin{array}{l}\text {-professional } \\
\text { Guernsey. } \\
\text {-back pain. } \\
\text { re dives } \\
\text { apeutic). } \\
\text { zness } \rightarrow \text { para- } \\
\text { a } 45 \mathrm{~min}\end{array}$ & $\begin{array}{l}5 \frac{1}{2} \text { bars }(45 \mathrm{~m}) 2 \text { hrs. } \\
\rightarrow \text { Cherbourg. } \\
\text { Decompression table } \\
\text { 'D' }\end{array}$ & $\begin{array}{l}\text { Paraplegia } \\
\mathrm{T}_{5}\end{array}$ & $\begin{array}{l}\text { Good. } \\
\text { Walks with } \\
\text { crutches }\end{array}$ & $\begin{array}{l}\text { Good } \\
\text { rehabilitation. } \\
\text { Euphoric }\end{array}$ \\
\hline $\begin{array}{l}7 \\
(1973)\end{array}$ & $\begin{array}{l}\text { Ama } \\
\text { (diat } \\
27 \mathrm{~m} \\
\text { Nor } \\
\text { Lost } \\
\text { ? Hy }\end{array}$ & $\begin{array}{l}\text { teur (34) } \\
\text { etic) Cornwall. } \\
\text { I5 min. } \\
\text { nal ascent. } \\
\text { consciousness. } \\
\text { poglycaemia }\end{array}$ & $\begin{array}{l}\text { H.M.S. Drake } 70 \mathrm{~m} \\
5 \text { hrs. } \\
\text { R.N.H. Plymouth. } \\
\text { Dexamethazone }\end{array}$ & $\begin{array}{l}\text { Cerebral + } \\
\text { quadriplegia }\end{array}$ & $\begin{array}{l}\text { Slight in } \\
\text { upper limbs. } \\
\text { Wheelchair }\end{array}$ & $\begin{array}{l}\text { Good } \\
\text { rehabilitation. } \\
\text { Euphoric }\end{array}$ \\
\hline $\begin{array}{l}8 \\
(1976)\end{array}$ & $\begin{array}{l}\text { Prof } \\
(28) \\
\text { (ope } \\
\text { Sud } \\
\text { Imm } \\
\text { quac }\end{array}$ & $\begin{array}{l}\text { essional diver } \\
\text { Diving bell } \\
\text { n) } 76 \mathrm{~m} \text {. } \\
\text { len ascent. } \\
\text { ediate } \\
\text { riplegia }\end{array}$ & $\begin{array}{l}\text { Immediate re- } \\
\text { compression to } 80 \mathrm{~m} \text {. } \\
\text { Later I.P.P.R. and } \\
\text { hyperbaric oxygen }\end{array}$ & $\begin{array}{l}\text { Quadriplegia } \\
\text { C5 }\end{array}$ & $\begin{array}{l}\text { Cervical } \\
\text { segments only }\end{array}$ & $\begin{array}{l}\text { Acute pul- } \\
\text { monary and } \\
\text { haematological } \\
\text { complications }\end{array}$ \\
\hline
\end{tabular}


arrival at the surface, then he immediately lost consciousness. It took about 12 minutes to close the Bell and to re-pressurise it from a surface pressure source. When he regained consciousness, he noticed that he was totally quadriplegic. The Diving Bell was then locked on to a larger decompression chamber and he was transported, by sea, to Aberdeen. On his journey he was treated with Rheomacrodex 3.5 litres, intermittent Solumedrol in doses of between 20 and $40 \mathrm{mg}$. He developed consumption coagulopathy and a pulmonary insufficiency syndrome (Fig. Ia and b) and as he had a virtually complete spinal cord lesion below $\mathrm{C}_{4}$ segment with diaphragmatic weakness, he was treated with intermittent positive pressure respiration. At the end of his 72 hours' decompression there was only a slight recovery in the $\mathrm{C}_{5}$ segment. He was subsequently treated with intermittent hyperbaric oxygenation. Over the first I8 days he had 1450 minutes of hyperbaric oxygen in 2-hour sessions. After 4 months he was transferred to Stoke Mandeville Hospital. By that time there had been a complete recovery of function in the right arm and a nearly complete recovery of function in the left arm. He still, however, had a complete transverse spinal cord syndrome below TI segment and there has been no subsequent recovery.

All the patients except for this last one had substantially incomplete spinal cord lesions and all were spastic. Patient 8 still has a complete lesion 5 months after injury and reflexes are just reappearing in the feet.

The four professional divers all complained of considerable pain in the limbs, were rather depressed, had many complaints, were compensation-minded and difficult to rehabilitate. In contrast, the amateurs and semi-professionals were cheerful, enthusiastic about their rehabilitation and made no complaints of pain, in fact two of them were so euphoric that I at first thought that they had sustained permanent brain damage. However, when I found that their visitors were of similar mentality, I realised that aqualung diving attracted a considerable number of 'underwater cowboys' who relished the risks involved in the sport.

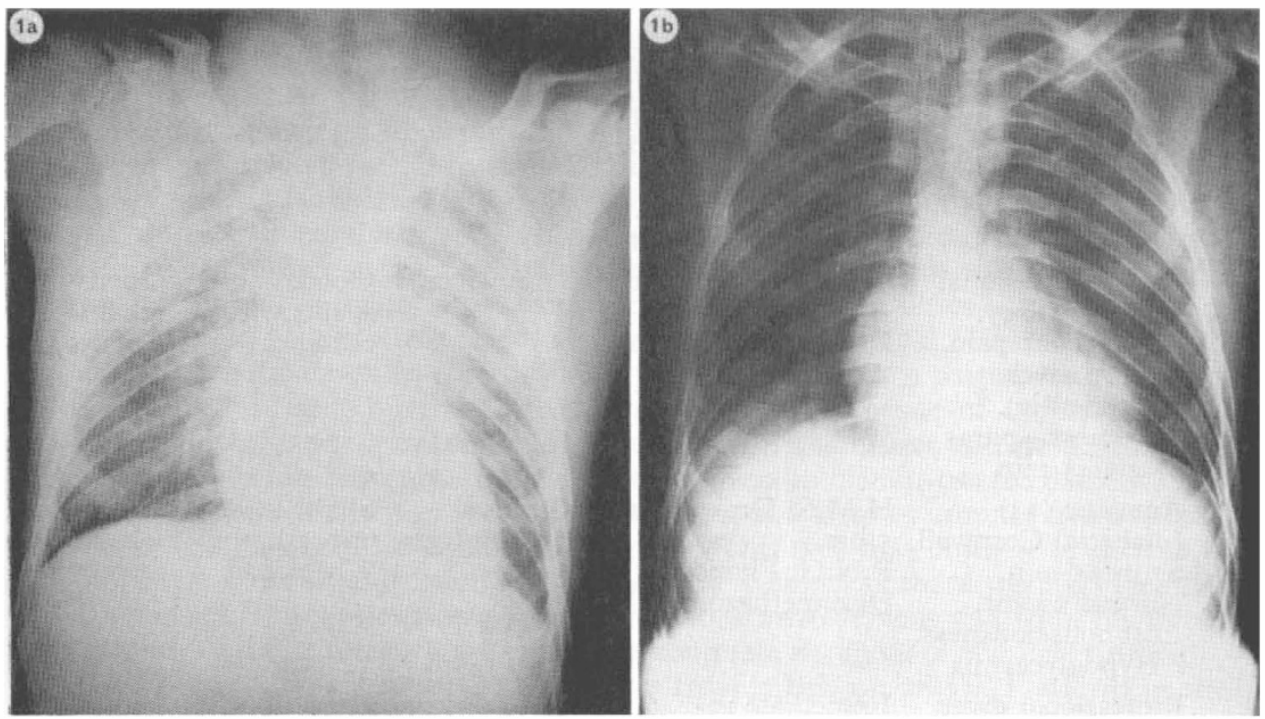

FIG. I

(a) Chest X-ray at 36 hours when he had developed pulmonary insufficiency syndrome. (b) Chest X-ray following institution of intermittent positive pressure respiration. 


\section{Pathology}

\section{Discussion}

In two of our patients ( 4 and 8), there was an extremely rapid ascent from a considerable depth, so it is possible that their neurological lesions were due to pulmonary barotrauma causing air emboli. In the other six cases, the lesions could only be due to decompression sickness. The underlying cause of decompression sickness is that the inert gases, nitrogen or helium, which have become dissolved in the body fluids and fat while the diver was at depth, come out of solution and form bubbles within the tissues and within the vascular system. The mechanisms involved have been reviewed by Elliott et al. (1974) and by Bennett and Elliott (1975). The most common minor manifestations of decompression sickness are limb bends and skin rashes and the commonest major manifestations are paralysis, dementia and bone necrosis.

In spite of the increasing popularity of diving, both for professional purposes and for sport, we have only admitted eight patients to Stoke Mandeville Hospital during the past I4 years and I have enquired of the other Spinal Injury Centres in England and they say they have had none. This is, therefore, fortunately a rare condition. The frequency of spinal cord involvement in decompression sickness relative to a brain involvement was already known at the beginning of the century (Bucquoy et al., 1908) and has been recently confirmed by Hallenbeck et al. (1975). For this reason, the theory that spinal cord involvement in decompression sickness was due solely to arterial bubble emboli was challenged by Haymaker and Johnson (1955) who postulated that bubbles formed in the epidural and retro-peritoneal fat enter the epidural vertebral venous system causing slowing of flow. More recently Hallenbeck and his co-workers (1975) working with anaesthetised dogs have suggested that spinal cord damage might be due to spinal cord infarction, secondary to obstruction of the epidural vertebral venous system with bubbles, this obstruction and slowing of flow was most marked in the presence of a grossly raised central venous pressure, but could also occur in the presence of a lower central venous pressure.

The history and final neurological status of our patients gives some indication of the possible pathological mechanisms. Two of our patients, numbers 5 and 6 , were able to return to a greater depth as soon as they developed neurological symptoms with complete relief of these symptoms; however, as they were diving with portable breathing apparatus, they could not maintain their dive and, on finally coming to the surface, paralysis recurred. This finding confirms that the pathology is initially reversible. Half our patients had lesions in their cervical cord, the other half in the upper dorsal region. All except Patient 8 had lesions which were eventually substantially incomplete and spastic, there being no zone of lower motor neurone damage apparent; this is in contrast to the findings of Taylor and Byrnes (1974); in experimental venous infarction of the cervical cord of rhesus monkeys, they found the major damage to be in the grey matter with no lesions in the white matter. None of our patients had respiratory embarrassment or 'chokes' before or at the time of onset of the paralysis, although Patient 8 developed a pulmonary insufficiency syndrome subsequently. From our observations, we cannot, therefore, draw any firm conclusions about the pathological processes involved in these cases; however, we can confirm the acute lesion is reversible, that the lesion is usually incomplete in the upper dorsal or cervical region and that there is a diffuse upper border to the lesion. The final neurological lesion is not typical of venous infarction. 


\section{Prophylaxis and Treatment}

Prophylaxis is by adequate decompression stops using accurate depth gauges. Evans et al. (1972) have demonstrated presence of intravascular bubbles in asystomatic divers, therefore, adequate training of divers should include emphasis on the danger of diving while under the influence of alcohol and the dangers of flying or travelling over mountain passes within 24 hours of diving. Professional divers should have recompression equipment and medical aid immediately available. Amateurs should be trained by, and obey the recommendations of their official National Associations.

Treatment, ideally, is by immediate recompression to at least the original depth; the greater the delay in recompression, the worse the prognosis. Oxygen should be given if there is any delay in recompression. The subsequent use of Rheomacrodex, dexamethasone, hyperbaric oxygen and possibly Heparin is justifiable in our present state of knowledge, but these agents are not of proven value.

\section{SUMMARY}

Eight patients with spinal cord lesions due to decompression sickness are described. The cord lesions were in the cervical cord in four cases and in the upper dorsal cord in the other four, seven patients had incomplete lesions, one had a complete lesion, all patients were spastic.

The diving details and description of the onset of paralysis are given and possible pathological processes are discussed. Prophylaxis is by adequate use of decompression stops. The most satisfactory treatment is immediate recompression.

\section{RÉsUMÉ}

On décrit huit cas de malades souffrant de lésions de la moëlle épinière entrainées par la maladie de la décompression. Les lésions de la moëlle étaient situées dans quatre cas dans la moëlleceervicale, et dans les quatre autres cas dans la partie supérieure de la moëlle dorsale; sept malades avaient des lésions incomplètes, un malade avait une lésion complète et tous les malades étaient infirmes moteurs cérébraux.

On donne les détails concernant la plongée et une description du début de la paralysie. On discute également les procédés pathologiques possibles. La prophylaxie s'effectue par une utilisation appropriée de dispositifs d'arrêt de la décompression. Le traitement le plus satisfaisant est la recompression immédiate.

\section{ZUSAMMENFASSUNG}

4 Patienten mit Rückenmarksschädigung auf Grund von Taucherkrankheit (Caisson oder Dekompressionskrankheit) werden beschrieben. In 4 Fällen war das Halsmark, in den anderen 4 Fällen das obere Dorsalmark betroffen.

Die Läsion war inkomplett in 7, komplett in I Fall. Bei allen bestand eine spastische Lähmung. Einzelheiten der Tauchertechnik werden gegeben, die Entwicklung der Lähmung werden beschrieben und die möglichen pathologischen Vorgänge diskutiert.

Prophylaxe besteht in angemessener schrittweiser Dekompression. Sofortige Rekompression ist die beste Form der Behandlung.

Acknowledgement. I am grateful to Mr J. Nelson Norman, M.D., Ph.D., F.R.C.S. of the Institute of Environmental and Offshore Medicine of the University of Aberdeen for details of the initial treatment and the X-rays of patient No. 8.

\section{REFERENCES}

Bennett, P. B. \& Elliott, D. H. (1975). The Physiology and Medicine of Diving and Compressed Air Work, 2nd ed. Baillière Tindall.

Bert, P. (1878). La Pression Barometrique. Masson, Paris. 
Boycott, A. E., Damant, G. C. C. \& Haldane, J. S. (I908). Prevention of compressed air illness. F. Hygiene (Lond.), 8, 342-443.

Elliott, D. H., Hallenbeck, J. M. \& Bove, A. A. (1974). Acute decompression sickness. Lancet, 2, II93-II99.

Evans, A., Barnard, E. E. P. \& Walder, D. N. (1972). Detection of gas bubbles in man at decompression. Aerospace Med., 43, I095-1096.

HallenbeCK, J. M., Bove, A. A. \& ElliotT, D. H. (I975). Mechanisms underlying spinal cord damage in decompression sickness. Neurology (Minneap.), 25, 308-316.

HAymakeR, W. \& Johnston, A. D. (1955). Pathology of decompression sickness. A comparison of the lesion in airmen with those in caisson workers and divers. Milit. Med., II7, 285-306.

Hill, L. (I9I I). Caisson sickness and compressed air. F. Roy. Soc. Arts, 59, 400-4I2.

Pol, B. \& Watelle, T. J. J. (I854). Mémoire sur les effets de la compression de l'air. Ann. Hyg. publ. (Paris), 2 sér. I, 24I-279.

TAYLOR, A. R. \& BYRNES, D. P. (I974). Foramen magnum and high cervical cord compression. Brain, 97, 473-480.

\section{General Discussion}

DR HARDY (Chairman). Thank you Hans again for still being there when the green light is on, which again means that we can have questions or comments from the floor, and I can perhaps exercise my privilege to reinforce what Hans has just said because there are seven Units in our small country and it is quite true that none of us in Sheffield, Oswestry and so on have had occasion to meet this problem and that the cases have gone to Stoke Mandeville, possibly because of their closer proximity to warmer waters than we in the cold North. I think it would be interesting to know from our American friends what happens to theirs, so if you've got any questions or comments may I have them.

DR GLEN REYNOLDS (U.S.A.). In California we have literally hundreds or thousands of underwater cowboys I would point out to Hans. In our group in Northern and Central California where the waters are a little colder than in Southern California we've only had two cases and they've both been amateurs, during the past 6 years, out of a total case load of around 650 patients. Both of these patients have made nearly complete recovery after having been initially rather extensively involved with multiple evidence of lesions not only neurologically but in the joints as well. The thing that I'm interested in, however, since you point out the paucity of these people, is that this membership perhaps might do a great service to themselves by having a sort of central registry, for instance at Stoke, that we could feed all of these cases into you and do a more extensive collaborative series so that we have a broader spectrum in this regard. The other thing of course that intrigues me, and you mentioned the problem of going through the mountain passes. In our situation the decompression equipment that is available along the Californian coast is largely centred in three areas, San Francisco, Monterey at the Navy Post-graduate Centre and at San Diego, all operated by the Navy. Many of these people are in danger of being recovered by the U.S. Coastguards and air evacuated by helicopter to the decompression centres and I think that is something else that should be brought to caution.

DR P. MINAIRE (France). I confirm that we have had three cases in 6 years. The last cases were 2 weeks ago and I would like to ask you if you have any experience of intrathecal steroids in the immediate treatment of these cases of decompression spinal cord injury.

DR Frankel. No, I have no experience of that but I would point out that a lot of experience of hyperbaric oxygen use does come from the French who have pioneered this method and it has only recently been taken up in Britain.

Dr MinaIRE. This one has been treated this way. In Nice, where they have a specialised service, he has been treated by hyperbaric oxygen and intrathecal steroids.

DR FRANKeL. I think the fact is we don't know where the critical blockage is. We aren't even certain that it's intravascular, there may indeed be a temporary compression of the spinal cord. Most of the evidence is that it is intravascular and the real treatment is immediate decompression. All other things we do afterwards when we've missed that main chance, I think are of borderline effectiveness. 